\title{
Is the Participation of Indonesian People in Exercise and Their Level of Physical Fitness Quite Sufficient?
}

\author{
Febriani Fajar Ekawati ${ }^{1 *}$, Sapta Kunta Purnama ${ }^{1}$, Islahuzzaman Nuryadin ${ }^{1}$ \\ ${ }^{1}$ Faculty of Sport, Universitas Sebelas Maret, Surakarta, Indonesia \\ "Corresponding author.Email: febriani@staff.uns.ac.id, saptakunta_p@yahoo.com, mase_islah@yahoo.com
}

\begin{abstract}
The level of physical fitness and participation in exercise is a part of an indicator of successes in sports development. Therefore, the measurement of those aspects is salient to support the government program. This study investigated intangible assets of Indonesian people using Sport Development Index (SDI) in 2017. Participants $(n=3400)$ from 34 provinces in Indonesia were tested their maximum oxygen uptake $\left(\mathrm{VO}^{2} \max \right)$. In addition, they filled out the participation dimension questionnaire. Result revealed that Indonesian people had low levels of physical fitness and their participation in exercise were insufficient. Additionally, Central Java residents had the highest score both in physical fitness and participation, while West Sulawesi and West Nusa Tenggara, and Papua residents were the lowest in both dimensions. Collectively, these findings suggest that SDI of Indonesia is relatively low.
\end{abstract}

\section{Keywords: Participation, physical fitness, sport development index}

\section{INTRODUCTION}

One of the UN General Assembly agendas for Sustainable Development Goals (SDGs) is to ensure healthy lives and promote well-being for all at all ages (United Nations General Assembly, 2015). They suggest implementing the new goals and targets based on the national policy space in every country that remaining consistent with relevant rules and commitments. Sport not only recognize as a catalyst for human and social development but also as a media to promote respect and understanding (Commonwealth Secretariat, 2011). The United Nations Inter-Agency Taskforce of Sport for Development and Peace defining sport as all forms of physical activity that contribute to physical fitness, mental well-being and social interaction, such as play, recreation, organized or competitive sport, and indigenous sports and games. Therefore, the value of sport can be considered as a development tool to support SDGs.

The indicator of success in sport development is not only measured by the number of medals obtained in the multisport events, but also can be assessed through the availability of public open space, human resources, participation, and the level of physical fitness, or well known as a Sport Development Index (SDI) (Mutohir and Maksum, 2007). The development of sport is a process that supports human being to have a lot of access to be physically active. In some regions of Indonesia, SDI with four dimensions of measurement has been applied to measure the level of the successes of sport development. Studies show that the index of SDI of people in the city of Wonogiri, Jambi, and Padang was categorized as low, the average number was around 0.31[1]-[3]. The two aspects of concern in those results were level of participation and physical fitness.

The dimension of participation refers to the number of community members in a region that conduct sport activities, such as competitive sports, indigenous sports, traditional games, and exercise. Data show that the level of participation in Jambi, Indonesia, was quite sufficient (0.57), while in Wonogiri was very poor (0.237) [1], [3]. Zulkarnaen(2001) reported that people in Bekasi, Indonesia has enough participation in sport especially Futsal. In addition, there was a positive and significant correlation between motivation and the level of participation among them. When the participation of community members increases, the level of physical fitness in that region will grow up along with the sport achievement.

Increasing physical fitness is one of approaches to obtain high level of sport development index in a country. To get high level of physical fitness, people must be physically active. The accumulation of physical activity throughout the day is one public health method. Undoubtedly, regular physical activity could reduce risk of developing many non-communicable diseases (NCDs) including cardiovascular disease, type 2 diabetes mellitus, some cancers, osteoporosis, dementia, Alzheimer's, and obesity [5], [6]. Despite these benefits, a review reported that participation in physical activity among adults is decreasing globally [7]. In line with this result, recent study that was conducted in Indonesia reported that Indonesia categorized (correctly) as the least physically active country in the world[8]. The sample of this study was only taken in Jakarta that is not represent all Indonesian people. 
To date, there is no information about the level of physical fitness and sport participation Indonesian people in all regions in Indonesia, despite clear data in several cities. This study tested the maximum oxygen uptake $\left(\mathrm{VO}^{2} \max \right)$ to obtain information about dimension physical fitness in Indonesia. We predicted that the level of physical fitness Indonesian people was low. Secondly, this study set out to test if participation in exercise among Indonesia people were sufficient. We predicted that almost people in Indonesia were insufficient to do exercise.

\section{METHOD}

\subsection{Participants}

Three thousand and four hundred people from 34 provinces in Indonesia were recruited for the study from August to November 2017. The sample consists of three categories: children aged $7-12$ years, adolescents aged 13 -21 years, and adults aged 22 years and above. They were asked to fill in the participation dimension questionnaire, after that do Multistage Fitness Test (MFT) (Australian Sports Commissions, 1991).

\subsection{Measures and Procedure}

After participants filled in the participation dimension questionnaire, they were instructed to be ready doing MFT. This test involves continues running between two lines $20 \mathrm{~m}$ apart. The participants stand behind one of the lines facing the second line and begin running when instructed by the recording. Once the participants failed to reach the line (within 2 meters) for two consecutive ends after the warning, the test must be stopped. After the score of this test was collected, the next step was to calculate the fitness index.

\subsection{Analysis}

All the data from 34 provinces were gathered using the specified instruments. The data from four dimensions of the SDI were then processed to find each of the index value. There are five categories of index value for every dimension, very good (> 0.90), good $(0.75-0.90)$, sufficient $(0.50-0.74)$, low $(0.24-0.49)$, and very low $(<$ 0.24) (Kristiyanto, 2012).

\section{RESULTS}

Figure 1 below summarizes the index value in every dimension and SDI of 34 provinces in Indonesia. The figure depicts the index value of physical fitness, participation, open space and human resources. In average, all the dimensions categorized as low since the index value was less than 0.49. Additionally, Central Java residents had the highest score both in physical fitness and participation, while West Sulawesi and West Nusa Tenggara, and Papua residents were the lowest in both dimensions. Follow-up analyses that calculated SDI revealed the index of sport development was low.

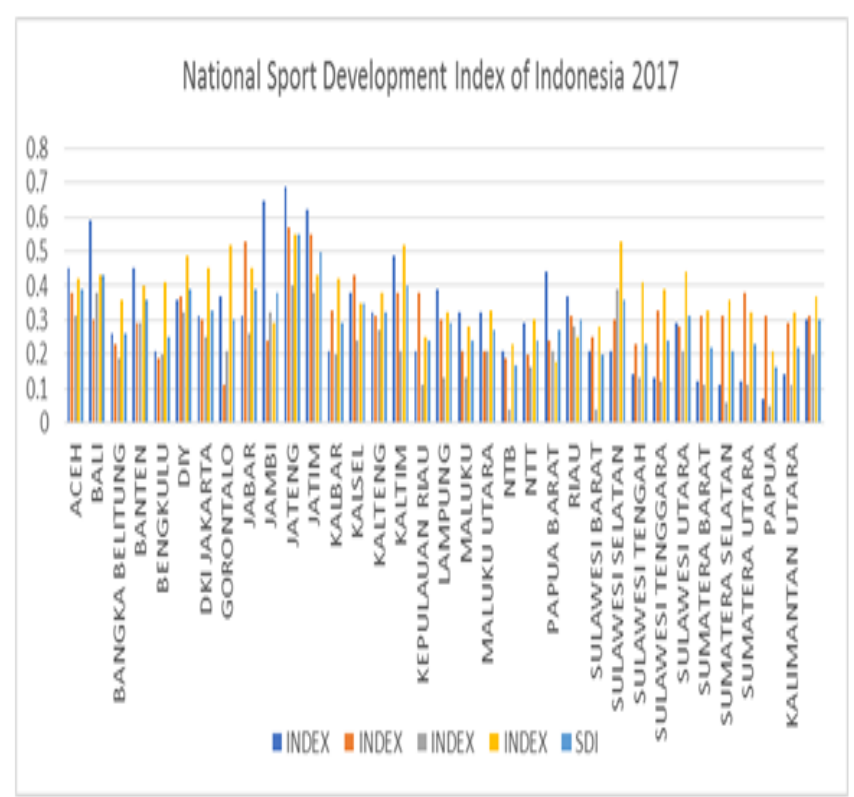

Figure 1 National Sport Development Index of Indonesia 2017

\section{DISCUSSION}

This study set out to investigate the level of participation and physical fitness Indonesian people taken from 34 provinces. In summary, the level of physical fitness and participation was low, the scores were under a sufficient category. In addition, the participation and physical fitness people in Central Java were the highest among people in other provinces. For the least position, West Sulawesi, West Nusa Tenggara, and Papua.

Sport Development Index is a standard to predict how successful sport development in a country. The indicator of success can be seen through four dimensions in SDI. In this study, the national index of participation was 0.32 which means below the standard of sufficient. Following this score, the level of physical fitness in Indonesia was also below the standard, with the index value 0.21 . It is possible that less participation in exercise causing low level in physical fitness.

When another dimension like the availability of open space involves in this discussion, it might give the supporting argument related to low level of sport participation and physical fitness. Without adequate space, people will have no chance to move. In addition, insufficient human resources in specific area might cause low level in both participation and the level of physical fitness. There are no enough people giving the information regarding the benefit of doing exercise or sport.

\section{CONCLUSIONS}

In summary, these findings suggest that Indonesian people has low participation in exercise and insufficient physical fitness. It might be caused by there are no adequate spaces for people to move or doing physical activity. This information, therefore, might be used to 
develop sport policy in Indonesia that can support sport development in the future.

\section{REFERENCES}

[1] D. Natalia, Sugiyanto, and Kiyatno, "Partisipasi Masyarakat dan Tingkat Kebugaran Jasmani Bagian dari Pembangunan Olahraga Kabupaten Wonogiri," J. Media Ilmu Keolahragaan Olahraga, vol. 6, 2016.

[2] K. Zalaff, M. F. Hidayatullah, and A. Kristiyanto, "European Journal of Physical Education and Sport Science SPOrts Human Resource Management Of Sport Development Index In Padang, West Sumatra , Indonesia - Evaluation Studies Of The Availability Of Sports Human Resource Management," Eur. J. Phys. Educ. Sport Sci., vol. 3, no. 3, pp. 97-104, 2017.

[3] S. Dasar and G. Decheline, "Hasil Pembangunan Olahraga Di Kota Jambi Ditinjau Dari Sport Development Index," J. Pendidik. Jasm. dan Olahraga, vol. 2, no. 2, pp. 61-71, 2017.

[4] Zulkarnaen, "Hubungan motivasi dengan partisipasi masyarakat dalam melakukan aktivitas olahraga futsal di kota bekasi," Motion, vol. 1, 2001.

[5] M. Reiner, C. Niermann, D. Jekauc, and A. Woll, "Long-term health benefits of physical activity - a systematic review of longitudinal studies," $B M C$ Public Health, vol. 13, no. 1, p. 813, 2013.

[6] D. E. Warburton, C. W. Nicol, and S. S. Bredin, "Health benefits of physical activity: the evidence," CMAJ, vol. 174, 2006.

[7] S. W. Ng and B. M. Popkin, "Time use and physical activity: A shift away from movement across the globe," Obes. Rev., vol. 13, no. 8, pp. 659-680, 2012.

[8] T. Althoff, R. Sosič, J. L. Hicks, A. C. King, S. L. Delp, and J. Leskovec, "Large-scale physical activity data reveal worldwide activity inequality," Nature, vol. 547, no. 7663, pp. 336-339, 2017. 